\title{
High glucose and high insulin conditions promote MCF-7 cell proliferation and invasion by upregulating IRS1 and activating the Ras/Raf/ERK pathway
}

\author{
MEI-LIN WEI* ${ }^{*}$ PENG DUAN ${ }^{*}$, ZHI-MING WANG, MIAO DING and PING TU \\ Department of Endocrinology and Metabolism, The Third Hospital of Nanchang, \\ Nanchang Key Laboratory of Diabetes, Nanchang, Jiangxi 330009, P.R. China
}

Received May 22, 2016; Accepted April 4, 2017

DOI: $10.3892 / \mathrm{mmr} .2017 .7420$

\begin{abstract}
Diabetes mellitus is associated with an increased risk of breast cancer, but the molecular mechanism underlying this association remains unclear. The aim of the present study was to investigate the effect of high glucose and high insulin conditions on MCF-7 breast cancer cells and to elucidate the molecular mechanisms underlying these effects. High glucose and high insulin conditions resulted in increased viability, proliferation, and invasion in MCF-7 cells compared with normal glucose and low insulin conditions. Reverse transcription-quantitative polymerase chain reaction and western blot analyses revealed that insulin receptor substrate 1 (IRS1) was significantly upregulated following high glucose and high insulin treatment compared with normal glucose and low insulin conditions. Furthermore, high glucose and high insulin treatment increased the Ras family of proto-oncogenes (Ras) and RAF1 proto-oncogene (Raf-1) protein expression, and activated the phosphorylation of extracellular signal-regulated kinase (ERK) 1/2. These findings suggest that high glucose and high insulin conditions promoted the proliferation and invasion of MCF-7 cells by upregulating IRS1 and activating the Ras/Raf/ERK pathway.
\end{abstract}

\section{Introduction}

Type 2 diabetes mellitus (T2DM) is a major public health problem worldwide. According to the International Diabetes Federation Diabetes Atlas 2015, there are 415 million people

Correspondence to: Professor Ping Tu, Department of Endocrinology and Metabolism, The Third Hospital of Nanchang, Nanchang Key Laboratory of Diabetes, 2 South Xiangshan Road, Nanchang, Jiangxi 330009, P.R. China

E-mail: tuping8877@126.com

*Contributed equally

Key words: type 2 diabetes mellitus, breast cancer, insulin receptor substrate 1, proliferation, invasion living with diabetes worldwide, and this number is expected to rise to 642 million by 2040 (1). T2DM constitutes $>90 \%$ of the cases of diabetes, and its prevalence has been dramatically increasing in developing countries, especially in China. T2DM is characterized by hyperglycemia, hyperinsulinemia, and subclinical chronic inflammation (2,3). Diabetic patients have increased risk of several types of malignancies, including breast, pancreas, liver, urinary tract, female reproductive organ, and colorectal cancer (4). Breast cancer is one of the most common cancers worldwide and has a high mortality rate in women (5). A recently reported meta-analysis revealed that women with diabetes had a significantly higher risk $(\sim 20 \%)$ of breast cancer than those without diabetes (6). Hyperinsulinemia and T2DM were demonstrated to be independent risk factors for postmenopausal breast cancer (7). In addition, accumulating data suggest that diabetes and its complications can adversely affect cancer therapy (8) and increase mortality (9), thus affecting the outcome of breast cancer patients $(10,11)$.

The insulin-like growth factor (IGF) and insulin receptors (IR) are important in breast cancer development and progression in T2DM patients (12-14). Insulin, not only elicits direct mitogenic effects through its actions on tumor cell growth, invasion and tumor-related angiogenesis (15), but also indirectly promotes estrogen and IGF response in both normal and malignant breast tissues (16). Insulin receptor substrate 1 (IRS1) is a regulator of insulin, IGF, and cytokine signaling, and therefore serves an important role in the proliferation, survival, and transformation of cells, by conveying signals to the phosphatidylinositol 3-kinase (PI3K)/AKT serine/threonine kinase 1 (Akt) and extracellular signal-regulated kinase (ERK) $1 / 2$ pathways. In general, the metabolic effects of insulin, such as glucose transport, are mediated by the PI3K pathway, whereas the mitogenic effects of insulin involve the mitogen-activated protein kinase (MAPK) pathway (17).

To date, the molecular mechanisms responsible for the association between diabetes and breast cancer are not well understood. The purpose of the present study was therefore to investigate the effect of high glucose and high insulin conditions on the proliferation and invasion of MCF-7 cells and to understand the molecular mechanisms underlying this effect. 


\section{Materials and methods}

Cell culture and treatment. MCF-7 breast cancer cells, purchased from the Institute of Cell Research of the Chinese Academy of Sciences (Shanghai, China), were cultured in Dulbecco's modified Eagle's medium (DMEM; Gibco; Thermo Fisher Scientific, Inc., Waltham, MA, USA) supplemented with $10 \%$ fetal bovine serum (FBS; Gibco; Thermo Fisher Scientific, Inc.) and antibiotics (100 IU/ml penicillin and $100 \mathrm{mg} / \mathrm{ml}$ streptomycin) in $5 \% \mathrm{CO}_{2}$ at $37^{\circ} \mathrm{C}$. The cells were cultured in normal glucose + low insulin $(5.6 \mathrm{mM}$ glucose $+5 \mathrm{nM}$ insulin) or high glucose + high insulin $(25 \mathrm{mM}$ glucose $+25 \mathrm{nM}$ insulin) conditions.

Cell viability and cell proliferation assays. The MTT cell viability assay is based on the conversion of MTT to violet-colored formazan crystals by mitochondrial dehydrogenases (18). For the MTT assay, the cells were seeded in 96-well plates at a density of $1 \times 10^{4}$ cells/well. The cells were allowed to attach and proliferate for $24 \mathrm{~h}$, and then subjected to the normal glucose + low insulin (5.6 $\mathrm{mM}$ glucose $+5 \mathrm{nM}$ insulin) or high glucose + high insulin $(25 \mathrm{mM}$ glucose $+25 \mathrm{nM}$ insulin) conditions for $24 \mathrm{~h}$. Then, the cells were incubated with $0.1 \mathrm{mg} / \mathrm{ml} \mathrm{MTT}$ at $37^{\circ} \mathrm{C}$ for $4 \mathrm{~h}$ and lysed in dimethyl sulfoxide at room temperature for $10 \mathrm{~min}$ to dissolve the formazan crystals. The absorbance in each well was measured at $570 \mathrm{~nm}$ using a SpectraMax i3 spectrophotometer (Molecular Devices, LLC, Sunnyvale, CA, USA) and the results were expressed as $\%$ of cell viability relative to the control cells.

For the proliferation assay, 5-Ethynyl-2'-deoxyuridine (EdU) was used. EdU is a nucleoside analog of thymidine that is readily incorporated into cellular DNA during DNA replication. Cell proliferation was evaluated using a Cell-Light EdU Apollo 567 In Vitro Imaging kit (Ribobio Co., Ltd., Guangzhou, China), according to the manufacturer's protocol. Briefly, the cells were incubated with $50 \mu \mathrm{M}$ EdU for $2 \mathrm{~h}$ at $37^{\circ} \mathrm{C}$, fixed with $4 \%$ formaldehyde, stained with the Apollo reaction cocktail and Hoechst 33342 as a nuclear counterstain, and protected from light. Images were acquired under a fluorescent microscope and the EdU positive cells (red cells) were counted in five random fields per sample. The EdU incorporation rate was expressed as the ratio of EdU positive cells to total Hoechst 33342 positive cells (blue cells). All experiments were repeated independently at least three times. ImageJ software v1.48 (National Institutes of Health, Bethesda, MD, USA) was used to generate overlapping images (19).

Total RNA extraction and reverse transcription (RT). Total RNA was extracted from cells using the TRIzol reagent (Invitrogen; Thermo Fisher Scientific, Inc.), according to the manufacturer's protocol. The total RNA was then converted to cDNA using the PrimeScript 1st strand cDNA Synthesis kit (Takara Bio, Inc., Otsu, Japan), according to the manufacturer's protocol.

Quantitative polymerase chain reaction ( $q P C R)$. qPCR was performed in a LightCycler 480 system (Roche Applied Science, Penzberg, Germany) using the SYBR Green Master Mix (Takara Bio, Inc.) (20,21). The following primers were used: IRS1, forward 5'-TTTGTGGTCCTTCCGTAGTT-3'
A

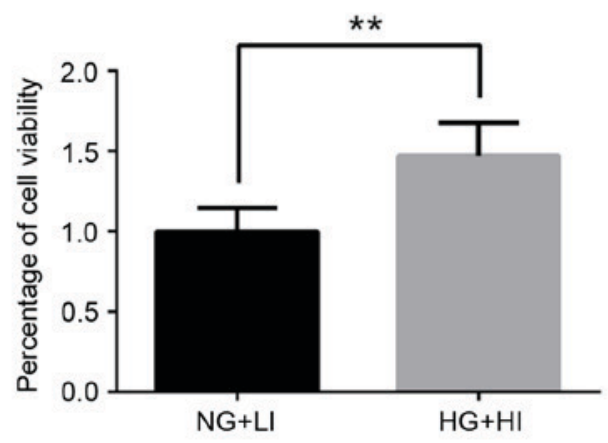

B
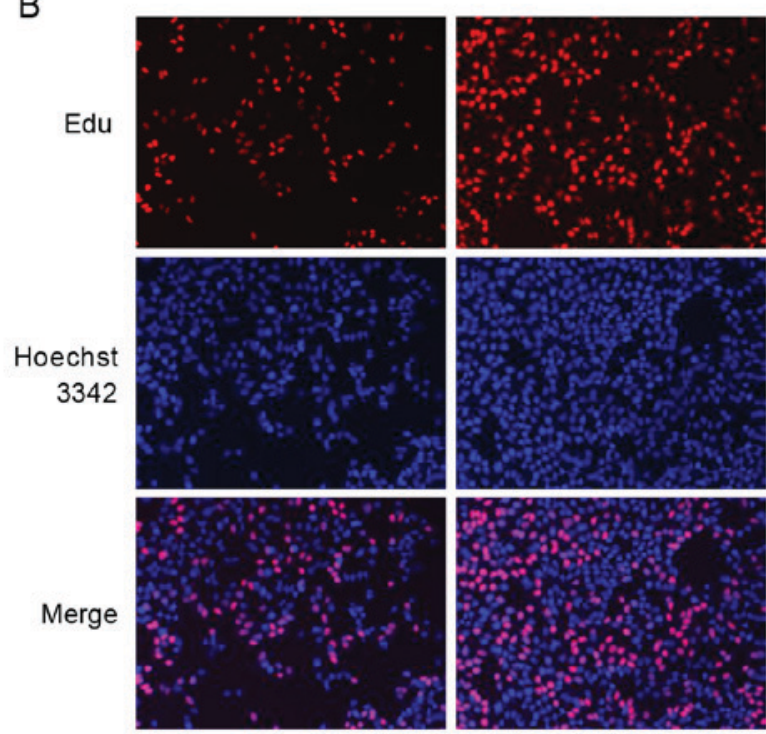

NG+LI

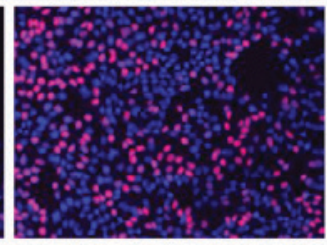

$\mathrm{HG}+\mathrm{HI}$

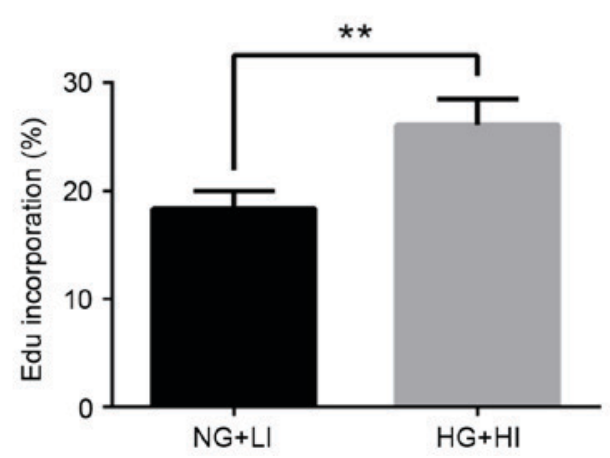

Figure 1. Effect of high glucose and high insulin on MCF-7 cell proliferation. (A) Cell viability was measured by MTT assay and presented as \% relative to the control NG+LI conditions. (B) Cell proliferation was evaluated by EdU-incorporation assay at $24 \mathrm{~h}$ following exposure to $\mathrm{HG}+\mathrm{HI}$ or $\mathrm{NG}+\mathrm{LI}$ conditions. Representative images of proliferating cells labeled with EdU (red) and with a Hoechst 3342 counterstain (blue). Magnification, $\mathrm{x} 100 .{ }^{* *} \mathrm{P}<0.01$. NG+LI: Normal glucose + low insulin; HG+HI: High glucose + high insulin; EdU, 5-Ethynyl-2'-deoxyuridine.

and reverse 5'-CCTGCCCCTAATGTGATGCT-3'; $\beta$-actin, forward 5'-AAGGTGACAGCAGTCGGTT-3' and reverse 5'-GTGTGGACTTGGGAGAGG-3'. The PCR conditions were: $95^{\circ} \mathrm{C}$ for $30 \mathrm{sec}$, followed by 40 cycles of $95^{\circ} \mathrm{C}$ for $5 \mathrm{sec}$ and $60^{\circ} \mathrm{C}$ for $30 \mathrm{sec}$. IRS1 gene expression was normalized to $\beta$-actin expression for each sample. The relative mRNA expression was calculated using the $-\Delta \Delta \mathrm{Cq}$ method (22).

Western blot analysis. Western blot analysis was conducted as described previously $(23,24)$. Briefly, the cells were cultured 
A
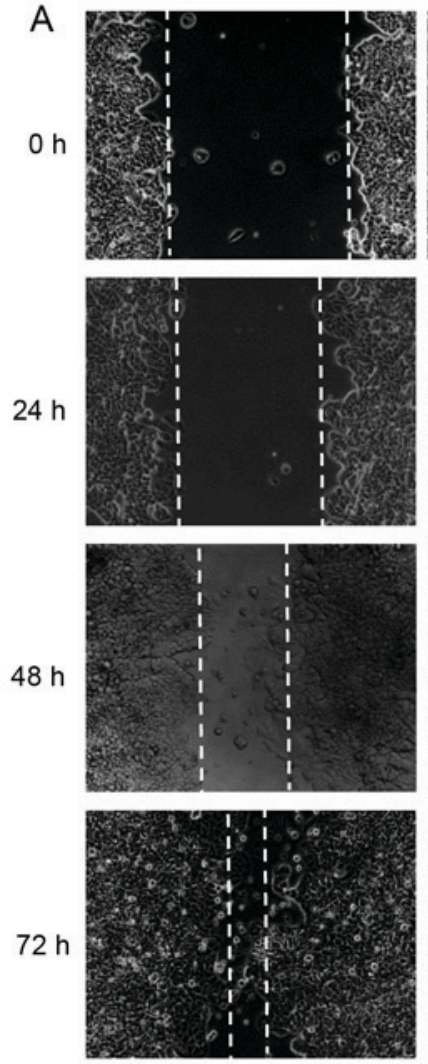

$N G+L I$

B

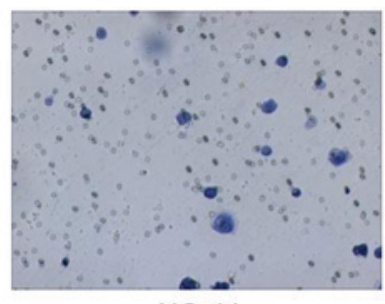

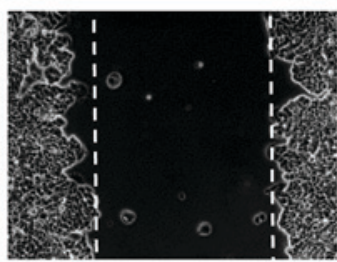
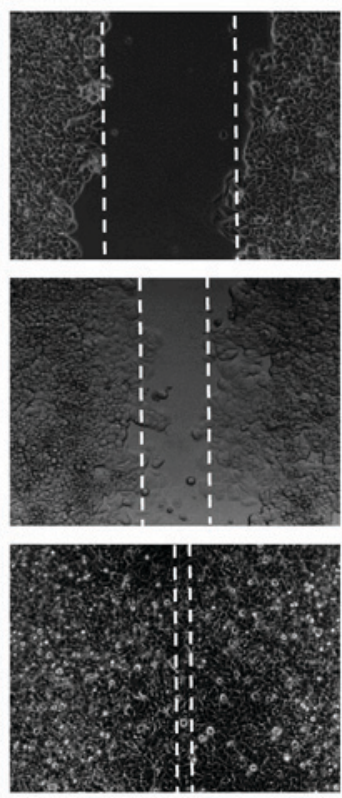

$\mathrm{HG}+\mathrm{HI}$

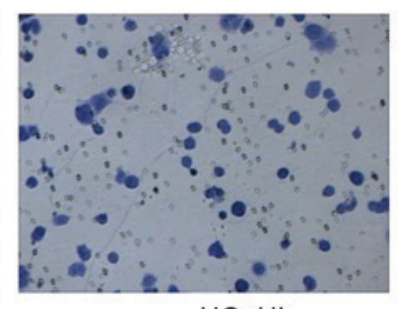

$\mathrm{HG}+\mathrm{HI}$
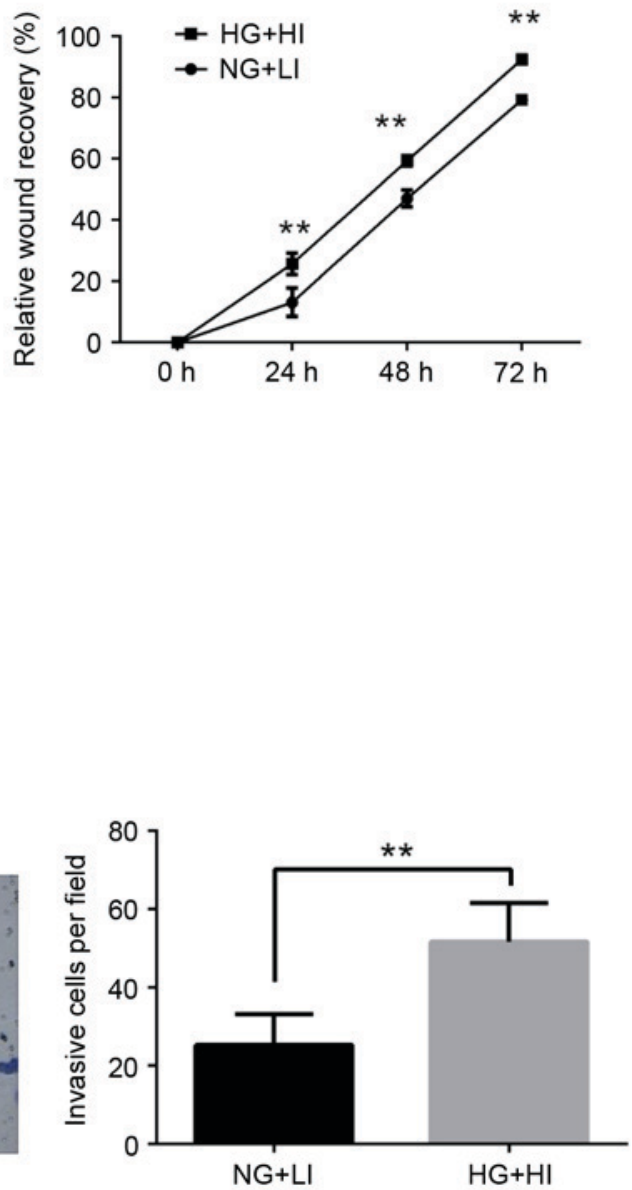

Figure 2. Effect of high glucose and high insulin on MCF-7 cell migration and invasion. (A) Migration ability was measured by wound healing assay and relative wound recovery was presented as \% recovery of the wound distance at 24, 48 and $72 \mathrm{~h}$ relative to $0 \mathrm{~h}$ (magnification, x100). (B) Invasion ability was assessed using transwell invasion assays (magnification, $\mathrm{x} 400$ ). ${ }^{* *} \mathrm{P}<0.01 . \mathrm{NG}+\mathrm{LI}$ : Normal glucose + low insulin; HG+HI: High glucose + high insulin.

under normal $(5.6 \mathrm{nM})$ or high-glucose conditions $(25 \mathrm{nM})$ for 2 weeks. Following overnight serum starvation, the cells were then incubated with low insulin $(5 \mathrm{nM})$ or high insulin $(25 \mathrm{nM})$ for $2 \mathrm{~h}$. Cells were washed with ice-cold PBS and lysed in Radioimmunoprecipitation Lysis Buffer (Beyotime Institute of Biotechnology, Shanghai, China) containing a $1 \%$ protease inhibitor cocktail (Beyotime Institute of Biotechnology). The cell lysates were spun at $10,000 \mathrm{x}$ g for $10 \mathrm{~min}$ at $4^{\circ} \mathrm{C}$, and the resulting supernatant was stored at $-80^{\circ} \mathrm{C}$. Protein concentration was determined using the bicinchoninic acid protein assay (Biyuntian Biotechnology Co.). The proteins were separated by $8-12 \%$ SDS-PAGE and transferred to polyvinylidene difluoride membranes (EMD Millipore, Billerica, MA, USA). The membranes were initially blocked with $5 \%$ nonfat dry milk in TBS $/ 0.1 \%$ Tween 20 for $1 \mathrm{~h}$ and then incubated with primary antibodies specific to IRS1 (cat. no. ab52167; 1:1,000; Abcam, Cambridge, MA, USA), tubulin (cat. no. MB0009; 1:5,000; Bioworld Technology, Inc., St Louis Park, MN, USA), phosphorylated (p)-ERK1/2 (cat. no. \#4377; 1:1,000; Cell Signaling Technology, Inc., Danvers, MA, USA), total ERK1/2 (cat. no.\#4695; 1:1,000; Cell Signaling Technology, Inc.), RAS proto-oncogene (Ras; cat. no. ab108602; 1:1,000; Abcam) and RAF1 proto-oncogene (Raf-1; cat. no. ab137435; 1:1,000; Abcam) at $4^{\circ} \mathrm{C}$ overnight. The membranes were then incubated with the appropriate horseradish peroxidase-conjugated secondary antibody (anti-rabbit IgG; cat. no. \#7074; 1:1,000; Cell Signaling Technology, Inc.) at room temperature for $2 \mathrm{~h}$. The immunoreactions were visualized using the Amersham Enhanced Chemiluminescence Plus western blotting detection reagents (GE Healthcare, Chicago, IL, USA), and the resulting band intensity was quantified using ImageJ software v1.48 (National Institutes of Health) (19).

Wound healing assay. To determine cell migration, MCF-7 cells were seeded in 6-well plates, incubated in normal glucose + low insulin (5.6 $\mathrm{mM}$ glucose $+5 \mathrm{nM}$ insulin) or high glucose + high insulin ( $25 \mathrm{mM}$ glucose $+25 \mathrm{nM}$ insulin) conditions and grown to confluence overnight. Wounds were made by scraping with a sterilized $10 \mu \mathrm{l}$ pipette tip, and cells were photographed under a phase contrast microscope (Carl 
Zeiss AG, Oberkochen, Germany) at 0,24 and $72 \mathrm{~h}$. The wound width was evaluated by measuring the distance between the two edges of the scratch in 5 random fields per plate; 3 plates/group were analyzed in total. Relative wound recovery was determined using the following formula: [(Wound width End time point - Wound width Starting time point $/$ Wound width Starting time $_{\text {. }}$ point $\mathrm{x} 100 \%$. All experiments were repeated independently at least three times.

Invasion assay. The cell invasion assay was performed using 24-well transwell chambers $(8.0 \mu \mathrm{m}$; Corning Incorporated, Corning, NY, USA). Cell suspensions were prepared in serum-free media containing $2 \times 10^{4}$ cells $/ \mathrm{ml}$, and $200 \mu \mathrm{l}$ of cell suspension was seeded into the upper chamber of transwells that were pre-coated with Matrigel (cat. no. 354234; Corning Incorporated). Then, $600 \mu 1$ of medium containing $10 \%$ serum was added to the lower chamber as the chemoattractant. After $24 \mathrm{~h}$ of incubation, the cells on the upper side of the transwell were removed using a cotton swab, and the filters were fixed with $100 \%$ methanol for $30 \mathrm{~min}$, followed by staining with Crystal Violet Staining Solution (Beyotime Institute of Biotechnology). For each chamber, four random fields were observed by phase contrast microscopy, and the average number of invading cells in each group was counted.

Statistical analysis. All experiments were repeated independently at least three times. Results were expressed as mean \pm standard deviation. Differences between two groups were assessed using the Student's t-test (two-tailed). Statistical analysis was performed using GraphPad PRISM 6 software (GraphPad Software, Inc., La Jolla, CA, USA). P $<0.05$ was considered to indicate a statistically significant difference.

\section{Results}

Effect of high glucose and high insulin on the proliferation of MCF-7 cells. Results from the MTT assay revealed that high glucose and high insulin culturing conditions resulted in increased viability in the MCF-7 cells compared with the control normal glucose and low insulin conditions (Fig. 1A). Additionally, results from the EDU cell proliferation assay demonstrated that MCF-7 cells exhibited increased proliferation under high glucose and high insulin culturing conditions, comparing with control conditions (Fig. 1B).

High glucose and high insulin conditions promote the migration and invasion of MCF-7 cells. To determine whether high glucose and high insulin conditions are associated with the progression of breast cancer, the effect of these conditions on the invasive behavior of MCF-7 cells was examined. Using a wound healing assay, the results demonstrated that high glucose and high insulin culturing conditions promoted MCF-7 cell migration, compared with control culturing conditions (Fig. 2A). In addition, the invasive ability of MCF-7 cells was significantly increased following exposure to high glucose and high insulin conditions, as determined using a transwell invasion assay (Fig. 2B). Taken together, these results indicated that exposure of MCF-7 cells to high glucose and high insulin conditions increased their migration and invasion ability.
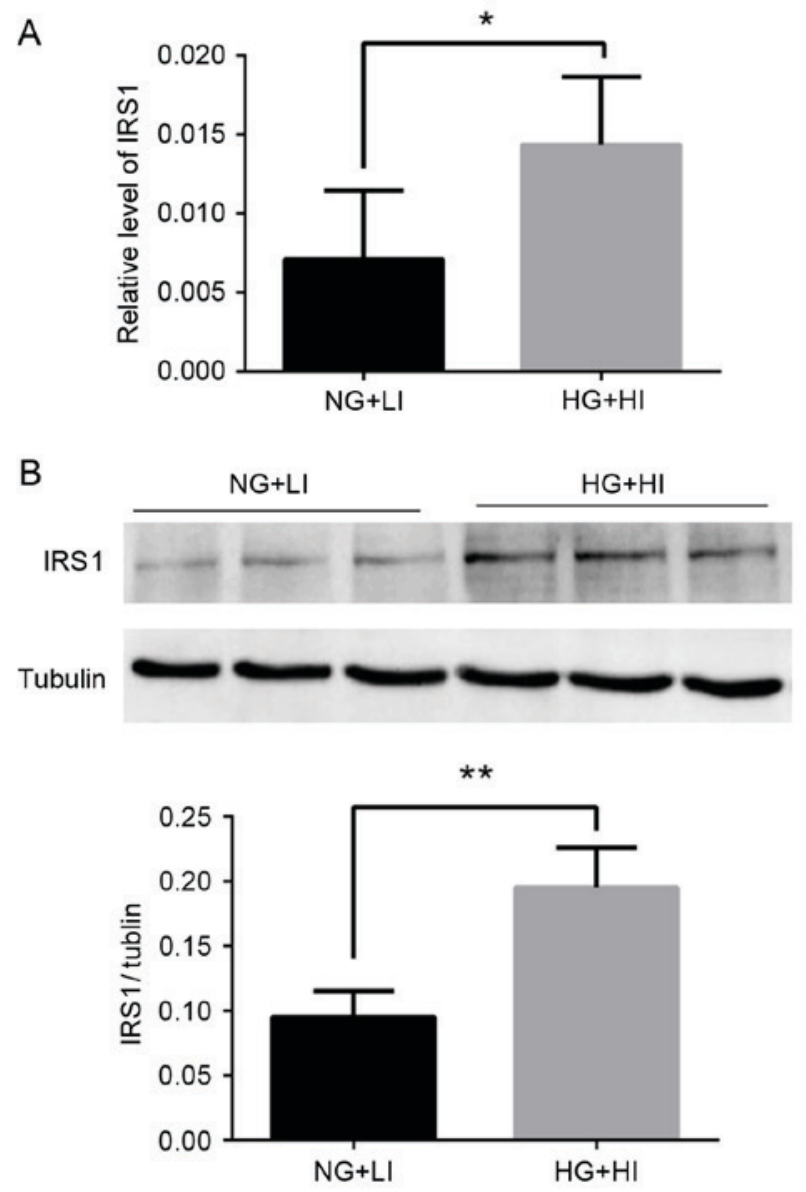

Figure 3. Effect of high glucose and high insulin on IRS1 expression. (A) Reverse transcription-quantitative polymerase chain reaction and (B) western blot analysis for the mRNA and protein expression levels of IRS1, respectively, in MCF-7 cells culture in NG+LI and $\mathrm{HG}+\mathrm{HI}$ conditions ${ }^{*} \mathrm{P}<0.05$ and ${ }^{* *} \mathrm{P}<0.01$. IRS1, insulin receptor substrate $1 ; \mathrm{NG}+\mathrm{LI}$ : Normal glucose + low insulin; HG+HI: High glucose + high insulin.

Exposure to high glucose and high insulin conditions upregulates IRSI in MCF-7 cells. In order to explore the potential mechanisms underlying the behavior of the MCF-7 cells exposed to high glucose and high insulin, the expression of IRS1 was examined by RT-qPCR and western blotting. IRS1 mRNA and protein expression was significantly upregulated following exposure to high glucose and high insulin culturing conditions compared with normal glucose and low insulin conditions (Fig. 3).

IRS1 promotes Ras-ERK pathway activation in MCF-7 cells. IRS1 promotes activation of the downstream Ras/Raf/ERK signaling pathway, which is important for the regulation of cell proliferation, apoptosis, and differentiation (25). This pathway was thus examined in the MCF-7 cells by western blotting. The results demonstrated that ERK1/2 phosphorylation increased significantly under the high glucose and high insulin culturing conditions compared with the normal glucose and low insulin conditions (Fig. 4). In addition, under the high glucose and high insulin culturing conditions, protein expression levels of Ras and Raf-1 were significantly upregulated (Fig. 4). The results suggested that, in MCF-7 breast cancer cells, ERK may be phosphorylated by the sequential activation of Ras and Raf-1, thereby inducing cell survival, proliferation, and invasion. 

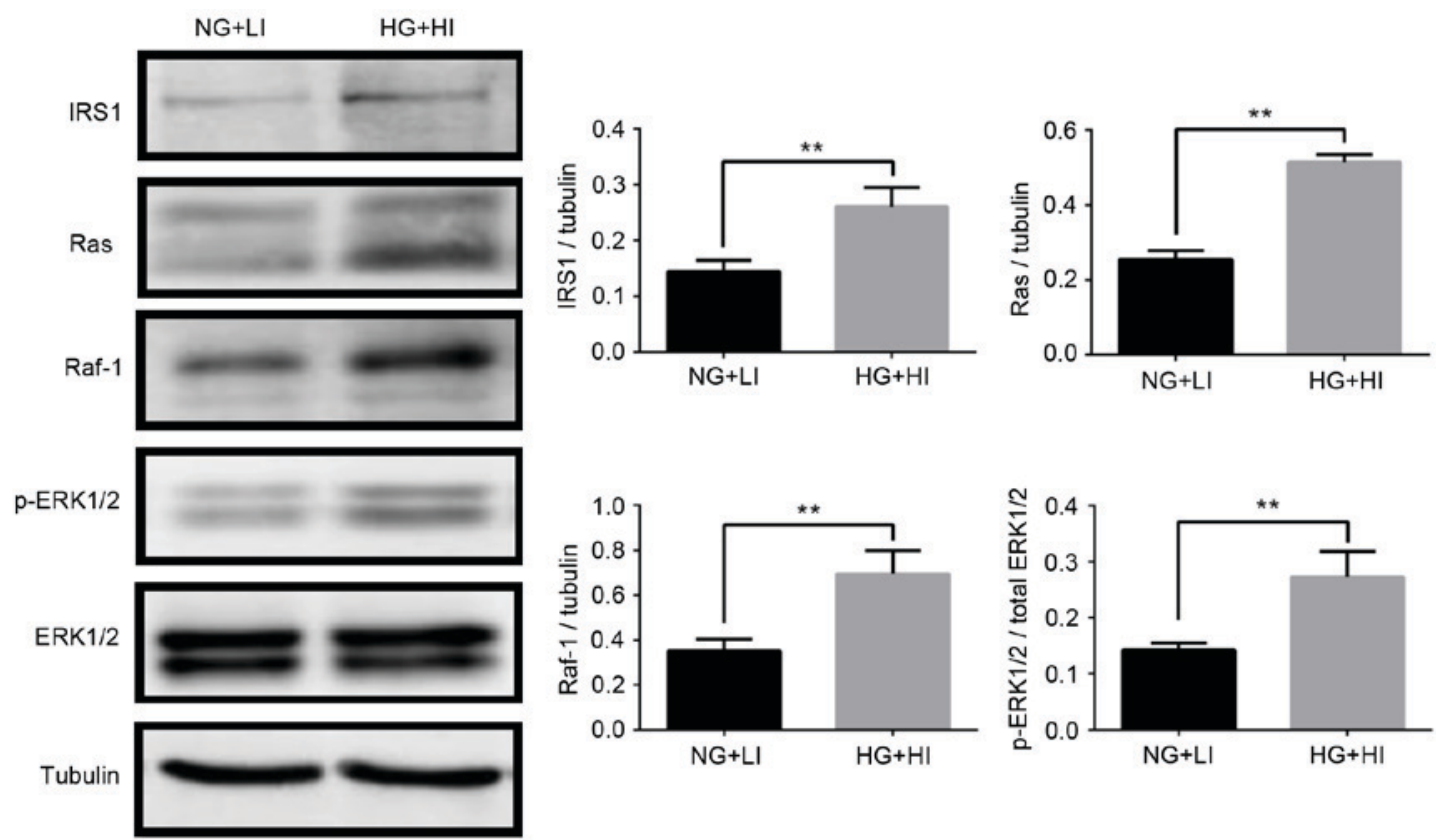

Figure 4. Effect of high glucose and high insulin on the ERK1/2 pathway. Protein expression levels of IRS1, Ras, Raf-1, p-ERK1/2 and total ERK1/2 in MCF-7 cells cultured in NG+LI and HG+HI conditions were examined by western blotting. Tubulin was used as a loading control. " $\mathrm{*}<0.01$. ERK, extracellular signal-regulated kinase; IRS1, insulin receptor substrate 1; Ras, the Ras family of proto-oncogenes; Raf-1, RAF1 proto-oncogene; p, phosphorylated; NG+LI: Normal glucose + low insulin; HG+HI: High glucose + high insulin.

\section{Discussion}

With the changing global lifestyle, the number of people suffering from T2DM is constantly increasing. Female diabetic patients have an increased risk of breast cancer and its related mortality. However, the relationship between diabetes mellitus and breast cancer remains unclear. The results of the present study demonstrated that high glucose and high insulin conditions promoted the proliferation and invasion of MCF-7 breast cancer cells by upregulating IRS1 and activating the Ras/Raf/ERK pathway.

Insulin resistance, which is characterized by hyperglycemia and hyperinsulinemia, is a major cause in the pathogenesis of T2DM. Insulin is a peptide hormone produced by the pancreatic b-cells, and it is well known for its involvement in cell survival and proliferation, as well as for its effect on mitogenic signals (26). Additionally, insulin receptors are frequently overexpressed in breast cancer cells $(27,28)$. Among the metabolic changes exhibited by cancer cells, an increase in glucose metabolism and glucose dependence is common (29). Elevated glucose levels directly promote the proliferation of tumor cells by functioning as a source of energy. As an adaptor of insulin, IRS1 has been demonstrated to act as an oncogene, and serve major roles in the growth, proliferation, migration, invasion, and differentiation of cells (30). Constitutive IRS1 activation is implicated in a variety of solid tumors, including breast cancer (31). The expression of IRS1 is increased in breast cancer tissues, with higher levels in the well-differentiated tumors compared with the poorly differentiated tumors (32). Because of the cross-talk between IGF signaling and estrogen receptor (ER) signaling pathways, IRS1 expression is regulated by estrogen in MCF-7 cells (33). MCF-7 is a hormonedependent breast cancer cell line due to its expression of ER.
Expression and activation of the ER enhances insulin mitogenicity by upregulating IRS1 and increasing PI3 K/Akt and MAPK signaling (34). High IRS1 expression is an indicator of early disease recurrence in ER-positive human primary breast tumors (35), and it indicates increased sensitivity to IGF-1 stimulated cell migration (36). Downregulation of IRS1 can suppress the growth of MCF-7 cells (36) and enhance the cytotoxic effects of tamoxifen (37). In vivo, transgenic mice overexpressing IRS1 have been reported to develop breast cancer and subsequent metastasis (38). Consistent with these previous studies, the present results demonstrated that IRS1 expression in MCF-7 breast cancer cells was increased following high glucose and high insulin culturing conditions compared with normal glucose and low insulin conditions.

MAPKs are known to be involved in transmitting extracellular signals that regulate cell growth, differentiation, and apoptosis (39), and to serve an essential role in MCF-7 cell cycle progression (40). Four dominating MAPK signaling cascades, the ERK1/2, ERK5, c-Jun N-terminal kinase (JNK) and p38 pathways, are implicated in normal function of mammary epithelial cells as well as the pathogenesis of breast cancer (41). Of these, the ERK-1/2 pathway is the most relevant to breast cancer (42). The Ras family of proto-oncogenes (comprising of H-Ras, N-Ras and K-Ras) encodes small GTP-binding proteins that transmit growth-promoting signals from the plasma membrane to the nucleus. This cascade involves predominantly three kinases. Upon the activation of Ras (a GTPase), Raf-1 acts as an MAPK kinase kinase and phosphorylates and activates MEK1/2, which then activates ERK1/2. Raf-1, a highly-conserved serine/threonine kinase of the MAPK pathway, serves a central role in the MAPK signaling pathway and is, thus, involved in proliferation, transformation, survival, and metastasis of cells. Active 
MAPK expression is significantly higher in breast tumors than in the adjacent normal breast tissue and may be a marker of breast cancer metastasis (43). The present results revealed that ERK phosphorylation and Ras/Raf-1 protein expression were significantly increased under high glucose and high insulin conditions, thereby indicating that the enhanced proliferation and invasion of MCF-7 cells may be due to activation of the Ras/Raf/ERK pathway.

Taken together, the present findings indicate that, in MCF-7 breast cancer cells, high glucose and high insulin conditions promoted cell proliferation and invasion by upregulating IRS1 and activating the Ras/Raf/ERK pathway. A better understanding of the mechanisms underlying the effects of high glucose and high insulin on breast cancer cells may aid in developing prevention strategies against disease progression.

\section{Acknowledgements}

The present study was supported by the National Natural Science Foundation of China (grant no. 81260133).

\section{References}

1. http://www.diabetesatlas.org/

2. American Diabetes Association: Diagnosis and classification of diabetes mellitus. Diabetes Care 33 (Suppl 1): S62-S69, 2010.

3. DeFronzo RA: Pathogenesis of type 2 diabetes mellitus. Med Clin North Am 88: 787-835, ix, 2004.

4. Vigneri P, Frasca F, Sciacca L, Pandini G and Vigneri R: Diabetes and cancer. Endocr Relat Cancer 16: 1103-1123, 2009.

5. Torre LA, Bray F, Siegel RL, Ferlay J, Lortet-Tieulent J and Jemal A: Global cancer statistics, 2012. CA Cancer J Clin 65: 87-108, 2015.

6. Larsson SC, Mantzoros CS and Wolk A: Diabetes mellitus and risk of breast cancer: A meta-analysis. Int J Cancer 121: 856-862, 2007.

7. Vona-Davis L and Rose DP: Type 2 diabetes and obesity metabolic interactions: Common factors for breast cancer risk and novel approaches to prevention and therapy. Curr Diabetes Rev 8: 116-130, 2012.

8. Zeng L, Biernacka KM, Holly JM, Jarrett C, Morrison AA, Morgan A, Winters ZE, Foulstone EJ, Shield JP and Perks CM: Hyperglycaemia confers resistance to chemotherapy on breast cancer cells: The role of fatty acid synthase. Endocr Relat Cancer 17: 539-551, 2010.

9. Lipscombe LL, Goodwin PJ, Zinman B, McLaughlin JR and Hux JE: The impact of diabetes on survival following breast cancer. Breast Cancer Res Treat 109: 389-395, 2008.

10. Jiralerspong S, Kim ES, Dong W, Feng L, Hortobagyi GN and Giordano SH: Obesity, diabetes and survival outcomes in a large cohort of early-stage breast cancer patients. Ann Oncol 24: 2506-2514, 2013.

11. Hou G, Zhang S, Zhang X, Wang P, Hao X and Zhang J: Clinical pathological characteristics and prognostic analysis of 1,013 breast cancer patients with diabetes. Breast Cancer Res Treat 137: 807-816, 2013.

12. Novosyadlyy R, Lann DE, Vijayakumar A, Rowzee A, Lazzarino DA, Fierz Y, Carboni JM, Gottardis MM, Pennisi PA, Molinolo AA, et al: Insulin-mediated acceleration of breast cancer development and progression in a nonobese model of type 2 diabetes. Cancer Res 70: 741-751, 2010.

13. Gallagher EJ and LeRoith D: The proliferating role of insulin and insulin-like growth factors in cancer. Trends Endocrinol Metab 21: 610-618, 2010

14. Rostoker R, Abelson S, Bitton-Worms K, Genkin I, Ben-Shmuel S, Dakwar M, Orr ZS, Caspi A, Tzukerman M and LeRoith D: Highly specific role of the insulin receptor in breast cancer progression. Endoc-Relat Cancer 22: 145-157, 2015 .
15. Michels KB, Solomon CG, Hu FB, Rosner BA, Hankinson SE, Colditz GA and Manson JE; Nurses' Health Study: Type 2 diabetes and subsequent incidence of breast cancer in the Nurses Health Study. Diabetes care 26: 1752-1758, 2003.

16. Mawson A, Lai A, Carroll JS, Sergio CM, Mitchell CJ and Sarcevic B: Estrogen and insulin/IGF-1 cooperatively stimulate cell cycle progression in MCF-7 breast cancer cells through differential regulation of c-Myc and cyclin D1. Mol Cell Endocrinol 229: 161-173, 2005.

17. Rose DP and Vona-Davis L: The cellular and molecular mechanisms by which insulin influences breast cancer risk and progression. Endocr-Relat Cancer 19: R225-R241, 2012.

18. Li Y, Wang K, Zou QY, Magness RR and Zheng J: 2,3,7,8-Tetrachlorodibenzo-p-dioxin differentially suppresses angiogenic responses in human placental vein and artery endothelial cells. Toxicology 336: 70-78, 2015.

19. Schneider CA, Rasband WS and Eliceiri KW: NIH Image to ImageJ: 25 years of image analysis. Nat Methods 9: 671-675, 2012.

20. Li Y, Wang K, Jiang YZ, Chang XW, Dai CF and Zheng J: 2,3,7,8-Tetrachlorodibenzo-p-dioxin (TCDD) inhibits human ovarian cancer cell proliferation. Cellular oncology (Dordrecht) 37: 429-437, 2014.

21. Wang K, Li Y, Jiang YZ, Dai CF, Patankar MS, Song JS and Zheng J: An endogenous aryl hydrocarbon receptor ligand inhibits proliferation and migration of human ovarian cancer cells. Cancer letters 340: 63-71, 2013.

22. Livak KJ and Schmittgen TD: Analysis of relative gene expression data using real-time quantitative PCR and the 2(-Delta Delta $\mathrm{C}(\mathrm{T})$ ) method. Methods 25: 402-408, 2001.

23. Li Y, Zhao YJ, Zou QY, Zhang K, Wu YM, Zhou C, Wang K and Zheng J: Preeclampsia does not alter vascular growth and expression of CD31 and vascular endothelial cadherin in human placentas. J Histochem Cytochem 63: 22-31, 2015.

24. Li HH, Zhao YJ, Li Y, Dai CF, Jobe SO, Yang XS, Li XF, Patankar MS, Magness RR and Zheng J: Estradiol 17 $\beta$ and its metabolites stimulate cell proliferation and antagonize ascorbic acid-suppressed cell proliferation in human ovarian cancer cells. Reprod Sci 21: 102-111, 2014

25. Shaw LM: The insulin receptor substrate (IRS) proteins: at the intersection of metabolism and cancer. Cell Cycle 10: 1750-1756, 2011.

26. Pollak M: Insulin and insulin-like growth factor signalling in neoplasia. Nat Rev Cancer 8: 915-928, 2008.

27. Papa V and Belfiore $A$ : Insulin receptors in breast cancer: Biological and clinical role. J Endocrinol Invest 19: 324-333, 1996.

28. Belfiore A, Frittitta L, Costantino A, Frasca F, Pandini G, Sciacca L, Goldfine ID and Vigneri R: Insulin receptors in breast cancer. Ann N Y Acad Sci 784: 173-188, 1996.

29. Hamanaka RB and Chandel NS: Targeting glucose metabolism for cancer therapy. J Exp Med 209: 211-215, 2012.

30. Bergmann U, Funatomi H, Kornmann M, Beger HG and Korc M: Increased expression of insulin receptor substrate-1 in human pancreatic cancer. Biochem Biophys Res Commun 220: 886-890, 1996.

31. Chang Q, Li Y, White MF, Fletcher JA and Xiao S: Constitutive activation of insulin receptor substrate 1 is a frequent event in human tumors: Therapeutic implications. Cancer Res 62: 6035-6038, 2002.

32. Sisci D, Morelli C, Garofalo C, Romeo F, Morabito L, Casaburi F, Middea E, Cascio S, Brunelli E, Andò S and Surmacz E: Expression of nuclear insulin receptor substrate 1 in breast cancer. J Clin Pathol 60: 633-641, 2007.

33. Molloy CA, May FE and Westley BR: Insulin receptor substrate-1 expression is regulated by estrogen in the MCF-7 human breast cancer cell line. J Biol Chem 275: 12565-12571, 2000.

34. Mauro L, Salerno M, Panno ML, Bellizzi D, Sisci D, Miglietta A, Surmacz E and Andò S: Estradiol increases IRS1 gene expression and insulin signaling in breast cancer cells. Biochem Biophys Res Commun 288: 685-689, 2001.

35. Lee AV, Jackson JG, Gooch JL, Hilsenbeck SG, Coronado-Heinsohn E, Osborne CK and Yee D: Enhancement of insulin-like growth factor signaling in human breast cancer: Estrogen regulation of insulin receptor substrate-1 expression in vitro and in vivo. Mol Endocrinol 13: 787-796, 1999.

36. de Blaquiere GE, May FE and Westley BR: Increased expression of both insulin receptor substrates 1 and 2 confers increased sensitivity to IGF-1 stimulated cell migration. Endocr Relat Cancer 16: 635-647, 2009. 
37. Cesarone G, Garofalo C, Abrams MT, Igoucheva O, Alexeev V, Yoon K, Surmacz E and Wickstrom E: RNAi-mediated silencing of insulin receptor substrate 1 (IRS1) enhances tamoxifen-induced cell death in MCF-7 breast cancer cells. J Cell Biochem 98: 440-450, 2006.

38. Dearth RK, Cui X, Kim HJ, Kuiatse I, Lawrence NA, Zhang X, Divisova J, Britton OL, Mohsin S, Allred DC, et al: Mammary Tumorigenesis and Metastasis Caused by Overexpression of Insulin Receptor Substrate 1 (IRS1) or IRS-2. Mol Cell Biol 26: 9302-9314, 2006.

39. Raman M, Chen $\mathrm{W}$ and Cobb $\mathrm{MH}$ : Differential regulation and properties of MAPKs. Oncogene 26: 3100-3112, 2007.

40. Weng LP, Smith WM, Brown JL and Eng C: PTEN inhibits insulin-stimulated MEK/MAPK activation and cell growth by blocking IRS1 phosphorylation and IRS1/Grb-2/Sos complex formation in a breast cancer model. Hum Mol Genet 10: 605-616, 2001.
41. Whyte J, Bergin O, Bianchi A, McNally S and Martin F: Key signalling nodes in mammary gland development and cancer. Mitogen-activated protein kinase signalling in experimental models of breast cancer progression and in mammary gland development. Breast Cancer Res 11: 209, 2009.

42. Santen RJ, Song RX, McPherson R, Kumar R, Adam L, Jeng $\mathrm{MH}$ and Yue W: The role of mitogen-activated protein (MAP) kinase in breast cancer. J Steroid Biochem Mol Biol 80: 239-256, 2002

43. Adeyinka A, Nui Y, Cherlet T, Snell L, Watson PH and Murphy LC: Activated mitogen-activated protein kinase expression during human breast tumorigenesis and breast cancer progression. Clin Cancer Res 8: 1747-1753, 2002. 